\title{
Õpimustritest muusikateose omandamisel klaveri algõppes
}

\author{
Veeda Kala \\ Eesti Muusika- ja Teatriakadeemia magister \\ veeda8@gmail.com \\ Jaan Ross \\ Eesti Muusika- ja Teatriakadeemia emeriitprofessor \\ Eesti Teaduste Akadeemia liige \\ jaan.ross@gmail.com
}

\begin{abstract}
Teesid: Käesoleva artikli aluseks on esimese autori tähelepanekud õpetajatöös, mis viitavad erinevatele õpimustritele muusikateose õppimisel. Olen täheldanud, et kuigi õpetan kõiki õpilasi võrdlemisi sama meetodiga, jäävad osadel õpilastel lood üsna kiiresti pähe ning nad mängivad ja harjutavad teoseid meelsamini peast. Teised õpilased eelistavad mängida noodist, toetudes noodile kogu õppeprotsessi vältel. Artikli eesmärk on selgitada tõenduspõhisel meetodil välja kirjeldatud õpimustrite esinemine ning kirjeldada neile iseloomulikke erisusi. Kui ilmneb eripärasid, mida on võimalik projitseerida erinevate õpimustrite tüpoloogiale, saab hakata uurima seoseid varasemalt eristatud õpistiilide ning sellealaste õpi- ja infotöötlusteooriatega. Samuti annab see võimaluse pakkuda välja rakendusi isikukesksemaks lähenemiseks klaveripedagoogikas nii õppeprotsessi kui ka õpilase-õpetaja koostöösuhte ning õpilase arengu tõhusamaks ja tulemuslikumaks, aga ka mõlemale osapoolele subjektiivselt meeldivamaks kujundamisel. Õpimustrite uurimiseks klaveri algõppes viisin läbi ja salvestasin videosse tunnid, mille raames on võimalikult sarnase taustaga õpilastele antud muuhulgas ka ülesandeid, mis testivad nende mälu ja noodilugemisoskust. Kogutud informatsiooni analüüsist tegin järeldused hüpoteetiliste intuitiivsete opimustrite olemasolu ja olemuse kohta. Seejuures lisavad formaalsel ja mitteformaalsel vaatlusel tehtud tähelepanekud materjali tulevasteks täpsemateks uuringuteks, viidates eelkõige, et kirjeldatud nähtust peaks käsitlema pigem kontiinumina, mis võimaldab hinnata õpilaste soodumust suuremal või väiksemal määral ühele või teisele poole ning sellest tulenevalt ka paremini kohandatud õpetamisstrateegiate rakendumist.
\end{abstract}

Märksõnad: algõpe, klaver, muusika, õpimustrid, õppimine

\section{Sissejuhatus}

Artikkel põhineb esimese autori tähelepanekutel ja uurimusel. Olen täheldanud nii oma praktikas klaveriõpetajana kui ka kuulnud oma õpetajatelt ja sama ala kolleegidelt nähtuse kohta, mille põhjal võib pianiste, aga eriti just noori klaveriõpilasi jaotada kaheks. Ühed on need, kellel on lihtsam, kiirem ja meeldivam 
lugeda teoseid noodist ning teoste esitamise kvaliteet on nende puhul noodist mängides kõrgem kui peast mängides. Teistel on lihtsam, kiirem ja meeldivam õppida teosed pähe ning ning nad saavutavad teose esitamisel kõrgema kvaliteedi peast mängides. Tean nii oma õpilaste kui ka tuntud pianistide seas näiteid, kuidas ühed eelistavad isegi kontserdil esitada teoseid noodist, samas jääb teistel kohe teost õppima hakates see juba pähe. Loomulikult saavad elukutselised pianistid üldiselt hakkama nii peast kui ka noodist mängimisega, sest see on paljuski treenitav, ent ometi on interpreetidel omad eelistused.

Kirjeldatud nähtus tundub olevat mitte juhuslik mitmekesisus vaid pigem korduv muster, mis mõjutab nii õppetööd, muusikute enesetunnet kui ka muusika esituse kvaliteeti. Seni on õpimustrite kujunemist pilliõppes uuritud vähe. Antud artiklis jälgitakse erinevate õpimustrite avaldumist klaveri algõpetuse praktikas.

Kui jälgimise tulemusel ilmneb eripärasid, mida on võimalik projitseerida erinevate õpimustrite tüpoloogiale, saab edaspidi uurida, millest need mustrid täpsemalt tulenevad: kas on see seotud varasemalt tõstatatud õpistiilide teooriatega, nt jaotus visuaalseks, auditiivseks ja kinesteetiliseks õpistiiliks (Fleming \& Mills 1992), erinevate mälusüsteemide kasutusega, erinevate kognitiivsete stiilidega või hoopis muuga; kas selliseid stiile võib eristada ka teiste pillide õppes, kuidas see mõjutab õpilaste erialavalikuid tulevikus ning kuidas saab õpetaja õpilaste eriilmelise õppimislaadiga paremini suhestuda ja töötada.

Võib arvata, et selgem teadmine ja lähtumine õpilaste õpistiilidest muusikaõppes teeks nii õpilase kui ka õpetaja töö lihtsamaks, tulemuslikumaks ja meeldivamaks, kuna katsed teistes õppevaldkondades on näidanud, et kui õpilasi õpetati nende õpistiilile vastavalt, tõusid õpilaste tulemused statistiliselt märkimisväärselt (Garcia 2002). Veel enam - tõhusaks õpetamiseks pole oluline mitte ainult õpilase õpistiil, vaid ka õpetaja oma. Seda eriti pilliõppe üks-ühele tunni tingimustes. Kui õpistiilide olemasolu klaveriõppes leiab kinnitust, võib õpilase ja õpetaja vaheliste konfliktide põhjus vähemalt osaliselt peituda nende õpistiilide erinevuses. Seega on võimalik, et õpistiilide uurimine instrumendiõppes aitab kergendada mitmete probleemide lahendamist.

Minu eesmärk on keskenduda noodilugeja-peastmängija mustri väljakujunemise jälgimisele ning vaadelda, milline täpsemalt ja kui selge see muster on. Selleks lähenen nähtusele induktiivse meetodiga, kogudes esmalt materjali, analüüsides seda, püüdes teha selle pinnalt järeldusi. Nii viisin kuue seitsmeaastase algaja õpilasega läbi 13-14 tundi, püüdes kõigil juhtudel säilitada võimalikult samalaadset õppeprotsessi.

Artikkel jaguneb nelja ossa: esimeses osas vaadeldakse algõpetust, noodist mängimist ja peast mängimist ning võetakse kokku teadmised õpistiilide kohta, teises osas kirjeldatakse praktilise töö meetodit, kolmandas osas kirjeldatakse ja analüüsitakse praktilise töö tulemusi ning neljandas võetakse töö kokku 
ning esitatakse lisa, kust leiab kirjaliku kokkuleppe blanketi töösse kaasatud laste eestkostjatega mõlemapoolse nõusoleku kinnitamiseks.

\subsection{Uurimistöö sihtgrupp ja klaveri algõpetus}

Kui laps saab seitsmeaastaseks, on ta Eesti kultuuriruumi mõistes jõudnud kooliikka ning riiklik haridussüsteem hakkab teda korrapäraselt ja mitmekülgselt arendama. Kuna haridussüsteem oma mitmekesisuses võib anda õpilastele küllalt erineva koolituse ja suuna, on vanemate kui seitsmeaastaste laste puhul järjest raskem näha õppuri enda loomupäraseid kalduvusi ja eeldusi, sest loogilist mõtlemist ning teadmisi saab õppida (ja õpetatakse) ja oskusi saab arendada (ja arendatakse).

Sealt edasi umbes kümnenda eluaastani muutub lapse mõtlemine Piaget'1 järgi operatsionaalseks ning areneb ka struktuuride ja printsiipide mõistmine. Selline areng iseloomustab nii üldist intellektuaalset muutust kui ka peegeldab muutusi muusikalises võimekuses: kasvab võime seostada muusikat “otseselt reeglite ja stiilitunnetusega, mäletada muusikalisi katkendeid ning nendega tajus opereerida, mis neile reeglitele ja stiilitunnustele vastavad" (Sloboda 1985: 194). "Seega märksa enam lootust on üldistuste tegemiseks algõpetuse kohta, kus võib loota, et õpilased kasutavad bioloogiliste kalduvuste ja enkulturatsiooniga määratud suurel määral ühiseid protseduure ja motivatsioonitegureid" (Sloboda 1985: 207). Nendel kaalutlustel valisin oma uurimistöö sihtrühmaks just seitsmeaastased varasema muusikalise süvaõppe kogemuseta lapsed suhteliselt samast piirkonnast, Tallinnast ja selle vahetust lähedusest - nii on nende enkulturatsioon võimalikult sarnane ning oskused veel välja treenimata. See annab lootust, et sihtrühma õpistiilide kohta tehtud üldistused tulenevad tõesti õpilaste endi loomusest.

Muusika on kõige vanem tööriist kõne-eelseks suhtlemiseks. Muusikaõpetus on juba ammustest aegadest olnud väga oluline osa inimese arengust. Muusikalise koolituse tulemusel areneb inimese ruumiline taju, abstraktne mõtlemine, loogiliste teisendustehete mõistmine, esteetiline tunnetus, suhtlemisoskus ja veel palju muud (Kirnarskaya 2009: 351-370). Muusikaõpetus on spetsiifiliste oskuste selgekssaamise meetod, mis rajaneb enkulturatsioonil. Enkulturatsiooni põhielementideks on (a) sünnipäraste või selle järel omandatud algeliste võimete kogum, (b) sellele järgnev hulk kogemusi, millega varustab kasvavat last ümbritsev kultuur, (c) ning viimaks kognitiivne üldsüsteem, mis sõltub paljude teiste kultuurile toetuvate võimete evitamisest (Sloboda 1985: 178) Klaveriõpe on üks võimalusest saada osa üldisemast muusikaharidusest, kus lisaks üldteadmistele õpetatakse klaverimängule eriomaseid teadmisi ja oskuseid. 
"Muusika esitamine on keerukas tahtlik somatosensoorne (ehk oma keha aistingutega seotud) käitumine, mis saab automaatseks laialdase harjutamisega koos auditiivse tagasisidega. See hõlmab kõiki motoorseid, meelelisi ning kuuldelisi piirkondi ajus" (Altenmüller \& Gruhn 2002: 63). Nii mitmekülgse keerukuse tõttu püütakse algõpetuses alustada väga tasapisi elementaarsetest teemadest, nagu istumisasend, sõrmenumbrid, klaviatuuritunnetus jne, ning järk-järgult liikuda keerulisema materjalini, mh lugude esitamine otsast lõpuni peast ja noodist. "Üldiselt arvatakse, et oskus(t)e õppes on kolm faasi" (Fitts \& Posner 1967, tsit Hallam \& Bautista 2012). Esimene neist on kognitiivne sõnalis-motoorne etapp, mida iseloomustab teadlik kontroll oma tegevuse üle, õpitavast arusaamine ja teadlik enesejuhtimine. Järgneb seostav etapp, kus tingitud refleksid liidetakse järgnevusteks, avastatakse ja parandatakse vead ning saavutatakse sujuvus. Viimases, iseseisvas etapis toimub teadliku pingutuseta automatiseerumine ja arengu jätk iga sooritusega, suureneb kiirus ja sujuvus. Kuna õpitavaid oskuseid on palju ja eri raskusastmes, on reaalsuses aktuaalsed sageli kõik kolm järku korraga, näiteks keerulise oskuse õppimise puhul on konkreetne komplitseeritud oskus alles kognitiivses faasis, samal ajal, kui selle oskuse õppimiseks vajalikud baasoskused on arenemas juba iseseisvas etapis, ehk teisisõnu - keerukat oskust õppides arenevad alateadlikult ka lihtsamad oskused, muutudes nii kiiremaks ja sujuvamaks. Seega on nimetatud arengujärgud oskuste õppimisel lahutamatult põimunud (Hallam \& Bautista 2012: 661).

Kuigi õpitava selgekssaamine toimub vähehaaval edasi liikudes, ei ole see sellegipoolest lihtne. Seetõttu on loomulik ja loogiline, et õpilane valib õpitava evitamiseks enda jaoks kõige loomuomasema ja mugavama tee ehk läheneb õpitavale teatud kindlat moodi, teatud stiilis. Seejuures on õppeprotsessi varastes staadiumites ülioluline, et õpetaja oleks toetav ja küllaltki mittekriitiline, tekitades entusiasmi ja muusikaarmastust. Väljakutseid ja konstruktiivset kriitikat ootavad arenguvõimelisuse säilitamiseks õpilased siis, kui nad on teinud õppijatena juba edusamme ja jõudnud kaugemale (Hallam \& Bautista 2012: 666).

Seega, kui laps alustab klaveriõpinguid, on tal olemas algelised teadmised ja kogemused teda ümbritsevast kultuurist. Kuna klaverimäng on peaaegu kõiki ajupiirkondi hõivav keerukas protsess, õpetatakse seda järk-järgult, hästi mänguliselt ja palju korrates, et närvivõrkudes saaks sisse töötatud õiged rajad. Oma uurimistöö sihtrühmaks olen valinud just seitsmeaastased kooliminevad klaverimängus algajad lapsed, sest nende arengutase on piisav ja küllalt tavaline klaverimängu õppimisega alustamiseks ning on tõenäoline, et nende õppimiseelistused ei ole saanud haridussüsteemis veel liialt mõjutusi. Ühtlasi püüan oma sihtrühma õpetamisel säilitada kõigi jaoks võimalikult sarnased 
tingimused: püüan õppetöös järgida siinsesse uurimusse kaasatud õpilastega samasugust plaani ning olen ise nende kõigi õpetajaks, et eri õpetajate õpetamisstiilidest tulenevad erinevused ei segaks tulemusi ja nende analüüsi ning ilmsiks saaks tulla õpilaste endi eelistused. Järgnevates alapeatükkides kirjeldan lühidalt noodist ja peast mängimise protsesse nii pedagoogilisest kui ka psühholoogilisest aspektist.

\subsection{Teose mängimine noodist - psühholoogilised protsessid ja õpetamine}

Loo noodist mängimise all pean siin silmas protsessi, kus õpilane esitab teost, jälgides samal ajal silmadega nooti ning mängides selle järgi. Ehk õpilane reageerib pidevalt visuaalsele informatsioonile noodis, reaktsiooni tulemusel teeb liigutuse, mille tagajärjel tekib heli, mida ta seejärel analüüsib - kas tulem oli oodatud või mitte -, ning vastavalt järeldusele kas proovib uuesti samale visuaalsele infolülile reageerida või liigub järgmise infoelemendi juurde. Sellesse protsessi on kaasatud mitmed tajusüsteemid ja ajupiirkonnad. "Psühholoogilisest vaatepunktist sisaldab noodist lugemine taju (noodimustrite lahtikodeerimine), liikumist (motoorse kava teostamine) ja mälu (mustrite äratundmine)" (Lehmann \& McArthur 2002: 135).

Vaadates nooti, otsib õpilane visuaalset teavet, mis annaks talle juhiseid käsiloleva teose mängimiseks. Need juhised on varasemalt õpitud, korratud ja talletatud pikaajalisse mällu. Märgates esimest juhiste kombinatsiooni (helikõrgus, -vältus, sõrmenumber) läheb see info läbi nägemisorgani ajju, täpsemalt talamusse, mis kannab sensoorsetest süsteemidest tuleva teabe edasi ajukoore nägemispiirkonda, kus dešifreeritakse infot ja seostatakse see vastavate teadmistega. Need omakorda käivitavad motoorsed protsessid väikeajus ja motoorsetes piirkondades, kus juhitakse, milline liigutus, millal ja millega tehakse. Kui antud info, sellele järgnev liigutus ning selle tulemusel tekkiv info on juba varasemast tuttavad, kujuneb välja sisemine kuulmine tänu kuuldelisele mälule, sest "kuuldeline mälu võimaldab kujutleda teose helisid, sh noodis eesseisvate sündmuste ootuseid ja samaaegseid hinnanguid esituse käigule" (Aiello \& Williamon 2002: 167). Kui liigutus on tehtud ning kuuldavale on tulnud heli, jõuab see läbi kuulmissüsteemi aju kuulmispiirkonda, kus heli analüüsitakse ning võrreldakse ootustega. Kui see vastab ootustele, minnakse edasi järgmise teabehulga juurde. Kui aga tekkinud heli ei vasta ootustele, juhib otsmikusagar protsessi kontrollimist, kuni jõutakse õige tulemini. Juhul, kui kuuldelises mälus ei ole tekkinud veel vastavaid mälujälgi, ei pruugi õpilane ainult auditoorsete andmete põhjal aru saada, kas noot oli õige või 
mitte. Sellisel juhul aitab tal protsessi kontrollida visuaalne info (oma käte jälgimine ning teadmised noodipildi ja klaviatuuri ehituse vastavustest). Kui nooti loetakse korduvalt, muutub oluliseks mälu. Hea meenutamisoskus aitab kaasa järgnevate läbimängude või korduvate väga sarnaste lõikude esituse paranemist (Lehmann \& McArthur 2002: 141).

Esimeste aastate instrumendiõppe õpilased (8-14aastased) kujutlevad nooditeksti kui sümbolite kollektsiooni ning peavad kõige olulisemaks mängida noote õigesti, jaotades mängimist õigeks või valeks (Bautista \& Pérez-Echeverria et al. 2009; Lopez et al. 2009, mõlemad Hallam \& Bautista 2012: 663 järgi). Kõige paremad noodilugejad Gary E. McPhersoni uurimuse kohaselt (2005) olid lapsed, kes võtsid kõige strateegilisema lähenemise ning uurisid enne alustamist loo detaile (milline on esimese takti tunnetus, mis on võtmemärgid, mis on taktimõõt ning millised on potentsiaalsed takistused ülejäänud loos), hoidsid oma tähelepanu probleemide ennetamisel ja muusikaliste märkuste lugemisel ning jälgisid ja hindasid ennast pidevalt, et parandada vigu (McPherson \& Davidson 2006: 338).

Selleks, et noodilugemine oleks algajale õpilasele jõukohane, tuleb enne tööd noodiga teha õpilasele tuttavaks kõik need osad mängust, mis ei puuduta visuaalse teabe haaramist: klahvide leidmine, klahvivajutused ja tekkivate helide kuulamine ja analüüsimine. Neid oskusi saab edendada improvisatsioonimängudega (mängutehnika, klahvide leidmine, kuulamine), õpilase poolt ise teoste väljamõtlemise (ilma kirja panemata) ja nende kordamisega (klahvide leidmine, kuulamine, analüüs) ning ka teoste õpetamise teel õigeid noote ette näidates. Seejärel saab liikuda edasi noodikirja juurde ning õpetada järk-järgult selgeks sellega seonduvad mõisted: noodijoonestik, takt, noot jne. Peale seda saab raskusastet reguleerida teoses sisalduvate erinevate elementide arvu arvestades. Mina oma praktikas püüan õpetada neid erinevaid aspekte (improviseerimine, loovad ülesanded, ettenäidatud ülesanded ja töö noodiga) õppetöös paralleelselt ehk igas tunnis natuke. Muutub vaid üksikute komponentide osakaal - esialgu tegeleb õpilane rohkem noodiväliste aspektidega, hiljem rohkem noodiga.

Kuigi noodilugemise edendamiseks on olemas erilaadseid võtteid, tehnikaid ja harjutusi, siis nii alguses, nagu on esimesed kolmteist tundi, puudutan ma neid vähesel määral ja ainult siis, kui see on otseselt oluline teose selgeks saamisel. Näiteks kui näen, et õpilasel tekivad teose noodist esitamisel soovimatud pausid iga noodi vahele ning see kipub kujunema harjumuseks, teen temaga harjutust, kus katan selle noodi ära, mille õpilane alla on vajutanud, et suunata teda vaatama kohe järgmist nooti. Üldiselt jätan erinevate noodilugemistehnikate (kaugemale vaatamine, nooditeksti känkimine mustrite, harmoonia ja võtete järgi jne) tutvustamise ajaks, mil elementaarne noodilugemine on juba 
piisavalt kinnistunud. Ühtlasi oli käesoleva uurimuse huvides mitte mõjutada lapse sooritust noodilugemistehnikate õpetamisega.

\subsection{Teose mängimine peast - psühholoogilised protsessid ja õpetamine}

Loo peast mängimise all pean silmas protsessi, kus teos on salvestunud õppija mällu ning ta mängib mälu järgi, vaatamata nooti. Selline olukord võib tekkida juba siis, kui teos ei ole lapsel veel päriselt selge. "Enamik lapsi õpib sellist uudset muusikaesituse kogemust, nagu seda on pillimäng, noodilugemisega samal ajal. See topeltkohustus võib osutuda tülikaks koormaks, mida paljud püüavad kergendada esimesel võimalusel iga uut teost pähe õppides nii, et nende esitus ei oleneks enam noodilugemise võimest" (Sloboda 1985: 73). Selle protsessi ahel sarnaneb suures osas noodist mängimisega, kuid erinevus seisneb info päritolus - ühel juhul tuleb see noodist, antud situatsioonis aga hoopis mälust.

Muusikalisse mälusse on kaasatud kuulmis-, nägemis- ja motoorne mälu. "Kuulmismälu (ehk auditiivne mälu) võimaldab inimesel kujutleda teose helisid, sh ootuseid tulemas olevatele sündmustele noodis, ja samaaegselt hinnata esituse käiku. Visuaalne mälu koosneb noodipiltidest ja teistest mängu kontekstuaalsetest aspektidest. Pianistid ja teised klahvpillimängijad võivad näiteks mäletada käe ja sõrme positsioone, akordikujude võtteid ja mustreid, mis tekivad klaviatuurile, kui neid mängida. Kinesteetiline mälu (ehk sõrme-, lihas- ja puutemälu) võimaldab esinejatel sooritada keerukaid motoorseid järgnevusi automaatselt" (Aiello \& Williamon: 167). Gary E. McPhersoni uurimuses (2005) olid parimad mälu ja kõrva järgi mängijad just need lapsed, kes sidusid muusika kõla otseselt sõrmestusega instrumendil (McPherson \& Davidson 2006: 338).

"Kajamälu ja varane töötlus annavad vahetu kogemuse hetke tabamisest muusikas teadliku (teadvustatud) tähelepanu fookuses ja aitavad segmenteerida seda kontrollitavateks üksusteks" (Snyder 2000: 15). Muusikat kuuldes moodustavad sündmused (helid), mille toimumine jääb lühimälu kestvuse piiridesse, meloodilise ja rütmilise taseme kogemuse. Nende tasemete peamine tunnusjoon on see, et need sündmused on ajalises plaanis grupeeritud olevikku. Sellel ajalisel plaanil on kaks dimensiooni, mida tajutakse kui kaht eri aspekti muusikalisest kogemusest: meloodiline ja rütmiline grupeerimine (Snyder 2000: 13-14). Selleks, et need rühmad talletuks pikaajalisse mällu, on oluline anda grupeeringutele tähendus, seostada see varasema kogemusega ning korrata neid ajaliste intervallide tagant. Pikaajaline mälu pakub konteksti, mis annab tähenduse, suhestades hetke käimasoleva kogemuse ja eelneva teadmise laiemasse raamistikku. Muusikakogemuse vormilise taseme 
moodustavad sündmuste rühmad, mis toimuvad lühimälu piiridest pikema aja jooksul, ning selle liigendus on seotud pikaajalise mälu struktuuri ja piirangutega. Erinevalt meloodilise ja rütmilise taseme mustritest on vormilise taseme mustrid nii suurel ajalisel skaalal, et neid ei saa hoomata olevikus ning nad ei säilita automaatselt oma ajalist järjekorda. Vormilise taseme sündmuste vaheliste seoste leidmiseks peavad need vähemalt osaliselt tulema tagasi teadvusse pikaajalisest mälust (Snyder 2000: 14-15).

Seega, kui õpilane mängib teost peast, on talle talletunud pikaajalisse mällu mitte ainult meloodilised ja rütmilised grupeeringud, vaid ka juba teose laiem vormiline struktuur, mille ta vähemalt osaliselt teadvusse tagasi toob, et teose sündmuste vahelised seosed leida, ning siis kuulmis-, nägemis- ja kinesteetilisest mälust juhindununa ette kannab.

Ka mälu kaasavate ülesannetega muusikas tegeletakse juba esimesest tunnist peale: improvisatsioonimängud (imitatsioonid, rondo-vormis improvisatsioon jne), omaloomingu mõtlemine ning ettenäitamise teel teoste äraõppimine. Muusikalise info salvestamisele aitab tegelikult kaasa ka igasugune teadmine muusikateooriast ja -struktuurist, seega võib öelda, et kaudselt arendan ma õpetajana lapse muusikalist mälu ka siis, kui enne teose õppima hakkamist uurime loo ülesehitust.

Loomulikult on olemas ka eraldi võtted teoste meeldejätmiseks (avaramate teadmiste abil harmooniast ja vormiõpetusest, aga ka tehniliste võtete ja kujundite abil), ent ka neid ma nii esimestes tundides veel ei õpeta. Me lihtsalt tegeleme looga nii kaua, kui tundub teose selgeks saamise huvides mõistlik, ning selleks ajaks on osadel õpilastel jäänud teos juba iseenesest pähe.

\section{4. Õpistiilidest}

Vaatamata sarnasele kasvukeskkonnale, "on arvestatavad individuaalsed erinevused samal tasemel algajate vahel" (Hallam 2001a, 2001b; Pitts et al. 2000a, 2000b; Renwick \& McPherson 2002; Sloboda et al. 1996 - kõik Hallam \& Bautista 2012: 662 järgi), mh ka muusikaga seotud nähtustes. "Muusika taju, esituse ja õppimise neuroloogilised alused tuginevad laialdaselt hajutatud närvivõrkudele mõlemas poolkeras, mis varieeruvad individuaalselt, [---] muusika õppimise läbi loodud närvivõrk võib sõltuda õpetamismeetoditest" (Altenmüller \& Gruhn 2002: 63). Seetõttu oli oluline õpetada antud uurimuses õpilasi võimalikult sarnase meetodiga, et välja saaks paista õpilaste endi individuaalne eripära ja omadus.

Õpistiilide tähendusväli on üsna lai, mistõttu on olnud keeruline seda üheselt defineerida. Õpistiilide teooria(d) kujunes(id) välja eksperimentaalsetest tule- 
mustest ja empiirilistest tähelepanekutest, et sünnipärased fundamentaalsed omadused on tihedas seoses kogu isiksusega ning mõjutavad õppimist (omandamisprotsesse), ning neid peetakse eelkõige praktikast lähtuvaks (Leppik 2006: 126-128). Üks õpistiilide etalondefinitsioone on "iseloomulikud kognitiivsed, efektiivsed ja psühhosotsiaalsed käitumised, mis funktsioneerivad suhteliselt stabiilsete indikaatoritena õppijate taju, interaktsiooni ja reaktsiooni kohta õpikeskkonna suhtes" (Curry 1981 Romanelli \& Bird et al. 2009 järgi). Õpistiile on eristatud erinevatel alustel suurel hulgal, samas pole ükski neist universaalsena aktsepteeritud ning kriitikud toovad välja nende kontseptuaalse raamistiku puudulikkuse nii teooriate endi kui ka nende mõõtmise/määramise juures (Romanelli \& Bird et al. 2009). Samas on õppimise efektiivsuse suurendamine aina kasvava õppijate arvu ning konkurentsi tõttu oluline teema ning sellest tulenevalt õpistiilid ja nendega seonduv lootustandev ja arenev uurimissuund.

Voldemar Tomusk eristab oma raamatus "Õpistiilid" kolme erinevat terminit - stiil, strateegia ja taktika: "Mõisteid rangelt eristades kasutatakse mõistet stiil isiksuse tasemel infotöötlust iseloomustava tunnuse tähenduses, strateegia väljendab õpilase lähenemise ühtsust erinevais õpiolukordades ning taktika kirjeldab spetsiifilistes õpiolukordades ilmnevat õpilase spetsiifilist jälgitavat tegevust. Stiili vaadeldakse indiviidi püsiva omadusena, strateegia on konkreetsest ülesandest tulenev. Strateegia on ajas muutuv ja õpitav, stiil vastupidi aga vaadeldav staatilise, indiviidi sisseehitatud omadusena" (Riding \& Cheema 1991 Tomusk 1993: 117 järgi). Kuna ma ei ole täielikult veendunud, millisega neist kolmest selles töös käsitletud kalduvuste puhul tegemist võiks olla ning selle väljaselgitamine eeldab pikaajalist uurimistööd (eriti just küsimuses, kas tegemist on indiviidi püsiva, n-ö sisseehitatud, või ajas muutuva omadusega), siis kasutan siin üldisemalt terminit õpimuster.

Õpistiile just muusikaõppe kontekstis on uuritud võrdlemisi vähe, kuid ka sellelt alalt leidub mõningaid uurimistöid. Enamasti on need siiski keskendunud muusika üldõppele või täpsemalt rütmidele, ent mitte klaveri või mõne muu pilli õppele. Sellele viitab ka Louisiana ülikooli klaveriosakonna professor Susanna Garcia, kes tõdeb, et õpistiile on pilliõppes vähe uuritud, kuid leiab, et see on oluline teema, ning on vaadelnud Fleming-Millsi õpistiilide jaotust (visuaalne, auditiivne ja kinesteetiline) just klaveriõppe vaatepunktist (Garcia 2002). Tema artiklis pole aga kirjeldatud täpsemat uurimiskäiku ega lisatud tõendusmaterjali. Ka Gary E. McPherson on uurinud laste oskuste arengut instrumendi algõppes ning leidnud, et lapsed kasutavad erisuguseid strateegiaid pillimängu õppimiseks, ent kõige edukamateks neist osutusid kõrvast-kätte ja silmastkõrva-ja-sealt-kätte koordinatsiooni oskused. Seejuures omandasid õpilased need meetodid pigem varjatult kui õpetaja otsesel juhendamisel (McPherson \& Davidson 2006: 339). 
On selge, et õpilaste vahel esineb individuaalseid erinevusi vaatamata sarnasele kasvukeskkonnale, ja on võimalik, et nende põhjal saab teha üldisemaid järeldusi ja jaotusi. Sellegipoolest pole seniajani jõutud üldtunnustatud ja tõenduspõhiselt vastavate teooriateni, sealhulgas ka muusikaõppes. Selles artiklis püüan teaduslikult ja tõenduspõhiselt uurida ja kirjeldada nähtust, mille kohta on kõige täpsem termin õpimuster.

\section{Meetod}

Minu eesmärk on jälgida erinevate õpimustrite avaldumist klaveri algõpetuse praktikas. Samataoliste tingimuste loomiseks on vaadeldavatel õpilastel sama õpetaja - mina ise -, et õpetamisstiili erinevuste mõju oleks potentsiaalselt väike. Samal eesmärgil pidasin esimese näidisõpilase puhul märksõnalist päevikut tundide sisu kohta ning järgmiste näidisõpilaste tundide läbiviimisel lähtusin peetud päevikust. Selge mustri väljajoonistumiseks kaasasin uurimistöösse kuus seitsmeaastast varasema muusika süvaõppe kogemuseta last ning õpetasin neid 13-14 akadeemilist tundi, sagedusega üks kuni kaks tundi nädalas. Sellise õppeprotsessi lõpuks olime õppinud ära teoseid nii ettenäitamise teel kui ka noodist, harjutanud noodilugemist ja peast mängimist, õppinud noote c'st g'ni ning õppinud mängima nii parema ja vasaku käega eraldi kui ka mõlema käega korraga. Õppeprotsessi jooksul toetusin peamiselt Reet Lantsoni klaverikoolile "Klaveriõpik lastele" (Lantson 2014), sest olen selle õpikuga kõige paremini tuttav ning mulle meeldib selle õpiku lähenemine ja süsteem. Samas ma ei leia, et õpiku valik selles töös erilist rolli mängiks, vaid pidin lihtsalt mingi valiku tegema ning tagama kõigile võrdsed tingimused. Seejuures kasutasin töölehti ja teoseid ka väljastpoolt õpikut (nt Riine Pajusaare lood "Kalendrilaul" ja "Pirukad"), selgitasin lastele mõningaid asju ise juurde ning olen õppeprotsessis kasutatud harjutusi ka ise välja mõelnud. Usun, et uurimistulemusi klaverikooli valik ei mõjuta, ent kahtluse tekkimisel võib tulevikus viia sama katse läbi mingi teise klaverikooliga.

Klaverimängu õpetamise koolkondi ning meetodeid on erinevaid, mistõttu kirjeldan lühidalt enda meetodit selles uurimuses osalenud õpilaste puhul. Üldises plaanis tutvustasin esimeses tunnis klaveri mehhanismi, klaviatuuri ja võtmeid, improviseerisime ning hakkasin õpetama teoseid ettenäitamise teel. Teises tunnis tegelesime rütmidega, tegime koordinatsiooni- ja rütmiharjutusi ning õppisime klaveriteoseid edasi (endiselt ettenäitamise teel). Kolmandas selgitasin taktimõõdu mõistet ning erinevaid taktimõõte, selle kõrval jätkasime klaveriteoste õppimist. Neljandas tunnis rääkisime noodijoonestikust ja nootide asetusest ning sealt edasi hakkasin tutvustama ükshaaval noote ja mängisime 
vaheldumisi nii päheõpitud teoseid kui teoseid noodist. Sellest hetkest alates suurenes noodist lugemise hulk järjest rohkem, kuni sai kuuendast tunnist alates peamiseks loo õppimise meetodiks. Seejuures mõned lood mängisime lihtsalt paar korda läbi, teistele aga keskendusime pikemalt. Minu varasema kogemuse põhjal joonistuvadki õpimustrite erisused välja siis, kui hakatakse teoseid päriselt selgeks õppima. Kui varasemalt oleme nii ettenäitamise abiga teoseid peast kui ka mitmeid teoseid noodist mängima õppinud, siis, kui jõudsime teoste selgeks õppimise juurde, tekkis erinevus: osad õpilased pidasid paremaks kasutada nooti ainult esmase abivahendina, et teos siis kohe meelde jätta ja seejärel veatuks harjutada; teistele meeldis pigem teost harjutada ja jälgida mängu ajal nooti. Selleks, et veenduda, kumba õppimislaadi õpilane kasutas, viisin teose õppimise viimistlemise astmes läbi ka katseid, kus palusin õpilasel mängida teost noodist, seejärel võtsin noodipuldilt noodi ja palusin teost uuesti mängida, mõlemal juhul vaatlesin õpilase reaktsiooni ning tema esituse kvaliteeti.

Iga tunni põhistruktuur oli ka sarnane: alustasime soojendusega, seejärel vaatasime teoseid ning vajadusel õppisime mingi uue asja (noot / märk / rütm / muusikateoreetiline element/ tehnika / teos vms) ning tunni teisel poolel tegelesime rohkem improvisatsiooni, muusikaliste mängude ja omaloominguga. Kuigi oludest tingituna tuli ette varieerumisi, püüdsin lähtuda alati eespool kirjeldatud ülesehitusest, sest üldjuhul on õpilased ärksamad ja suurema tähelepanuvõimega pigem tunni alguses. Uurimistöös osalenud õpilastele püüdsin säilitada võimalikult loomulikku ja tavapärast klaveriõppe keskkonda. Ainuke, mis tavapärasest nende jaoks erines, oli see, et tunnis oli alati seade, mis tundi salvestas.

Esimene töös osalenud õpilane tuli vabatahtlikult minu juurde õppima seoses minu pedagoogilise praktikaga Eesti Muusika- ja Teatriakadeemias. Nõudeid õpitavale ei olnud ning kuigi semestri lõpus ootas ees esinemine, järgnes selle tarbeks loo pähe õppimine alles pärast uurimistööks vajalike tingimustega tundide läbitegemist. Kuna õpilane vastas kõigile uurimistöös olulistele tingimustele ning ka tema eestkostja oli nõus lapse osalemisega uurimistöös ja tundide filmimisega, otsustasin ta oma töösse kaasata. Ülejäänud viis töös osalenud õpilast leidsin, pannes sotsiaalmeediaportaali Facebook üles kuulutused, kus märkisin, et otsin õpilasi, kes oleksid seitsmeaastased, varasema muusika süvaõppe kogemuseta, valmis käima klaveritunnis Tallinnas, pillimängust huvitatud, iseseisva harjutamise võimalusega ning kelle vanemad on nõus allkirjastama kirjaliku kokkuleppe, mille alusel ja tingimustel võtan tunnid oma uurimistöö tarbeks videosse. Nii ei olnud leitud õpilastel muusikakooli või mõne muu institutsiooni poolt kohustusi esineda (ja selleks lugusid pähe õppida), vaja täita mingeid tähtajalisi nõudeid või muud taolist ning saime õppetöös lähtuda vaid õppimiseks, õpetamiseks ja uurimistöö jaoks vajalikest 
tingimustest. Kuulutusi oli üleval kaks: joonisel 1 on kuulutus, mis oli üleval 2019. aasta veebruaris ning joonisel 2 on kuulutus, mis oli üleval 2019. aasta septembris. Esimese kuulutusega leidsin kolm õpilast, teise kuulutusega leidsin veel puuduolevad kaks õpilast.

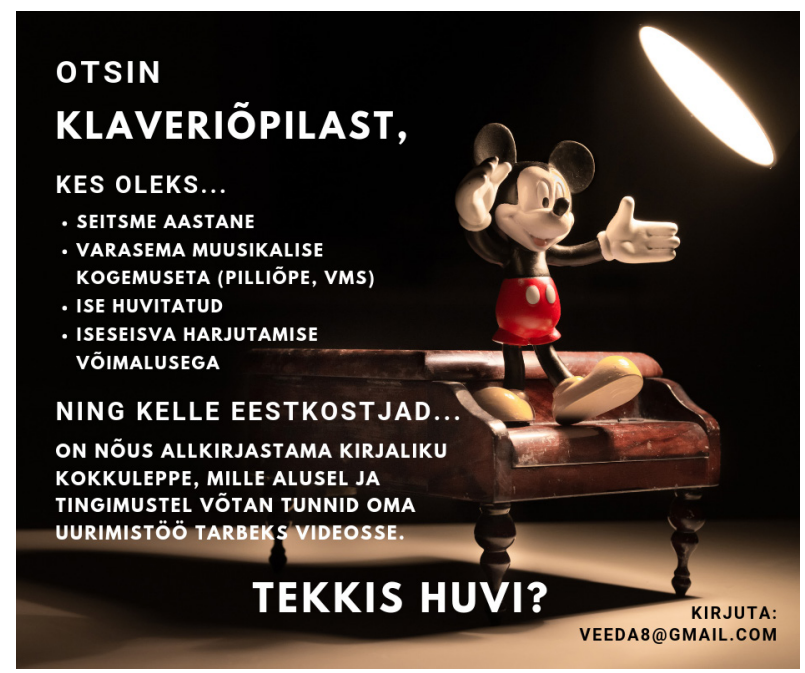

Joonis 1. Kuulutus, mis oli üleval 2019. aasta veebruaris.

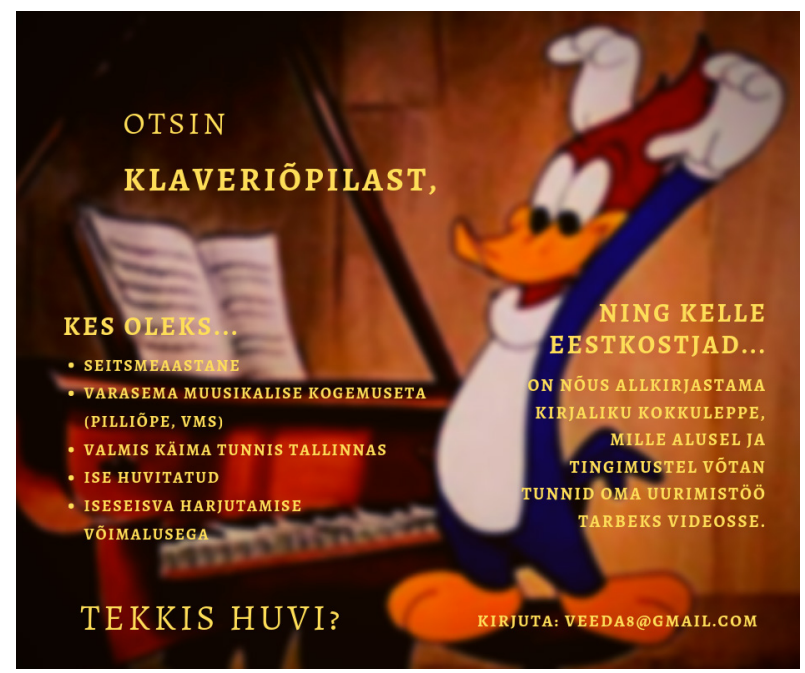

Joonis 2. Kuulutus, mis oli üleval 2019. aasta septembris. 
Õpilase tunnid salvestasin videosse ning selleks sõlmisin lapse eestkostjaga vastava kirjaliku kokkuleppe (vt Lisa 1). Tunde lindistasin oma telefoniga (Xiaomi Mi A2), ent üks kord salvestasin arvutiga (Dell Latitude E6320, vabavaralise programmiga "Free Cam 8"). Tundide salvestamine toimus mõne kuu vältel, alates õppe esimestest tundidest kuni 13.-14. tunnini ehk õpimustri väljajoonistumise märkideni. Kuigi sellise tundide arvu ja sagedusega peaks tunnid kestma kolm kuud, varieerub lõplik kestus sõltuvalt koolivaheaegadest, õpilaste tervislikust seisundist ning korralduslikest küsimustest (transport, erakorralised sündmused jne). Salvestisi saab kasutada tõendamaks, et olen õpetajana tegelenud nii noodist mängimise kui ka päheõppimise poolega ega ole ühte teisele olulisel määral eelistanud.

Videote põhjal toon välja kolm lugu, millega on tundides põhjalikumalt tegeldud alates nootide õppimisest kuni (enam-vähem) sujuva esituseni ning millest saavad näited antud õpilase õpimustri eelistuse väljajoonistumise kohta. Selleks, et tingimused oleksid kõigil õpilastel võimalikult sarnased, valin näiteks toodavateks teosteks kõigile samad: "Elevandi marss" (autor R. Lantson), "Juba linnukesed" (eesti rahvaviis, sõnade autorid on K. A. Hermann ja P. Tekkel) ja "Aisakell" (tuntud jõululaul, autor J. S. Pierpont, eestikeelse teksti autor on H. Karmo) Reet Lantsoni klaverikoolist.

Valisin just need teosed mitmel põhjusel. Esiteks arvestades raskusastet: "Elevandi marss" on teos, kus on ainult kaks nooti ja see on mängitav ühe käega; "Juba linnukesed" on ka veel ühe käega mängitav, ent siin on kasutusel juba viis nooti; teoses "Aisakell” on kasutusel viis nooti mõlemas käes ning selle mängimiseks on vaja kahte kätt. Kõige lihtsam lugu neist on ka kõige võõram - see on õpiku autori enda väljamõeldud just selle õpiku tarbeks. Teised kaks on traditsioonilised lastele üldiselt juba tuttavad laulud ja sageli oskavad lapsed neid ka peast laulda. Oskuse neid klaveril mängida või noodist ära tunda omandavad nad aga alles klaveriõppe käigus. See, et need laulud on juba tuttavad, aitab küll tänu sisemise kuulmise võimele teosed kiiremini selgeks saada ja sellest tulenevalt ka paremini pähe õppida, ent kuna kõigile õpilastele avalduv mõju on ühesugune (sest "Juba linnukesed" ja "Aisakell" on Eesti kultuuriruumis laialt levinud), ei tohiks see osutuda segavaks teguriks õpilaste omavahelisel võrdlemisel. Nagu tulemustest näha, leidub ka nende lugude puhul nii neid, kellele lood jäid pähe, kui ka neid, kellele lood pähe ei jäänud.

Kogu töö käigu kuni selgekssaamiseni olen litereerinud (vt artikli kolmandat jagu). Seejärel analüüsin näiteid nii litereeringute kui ka videote põhjal, vaadeldes õpilase silma- ja käeliigutusi, vigu ja nende olemust, õpilase arvamusavaldusi ja minu enese tähelepanekuid ning teen järeldused vastava õpilase soositud õpimustri kohta. Iga näite lõppu olen lisanud ka kommentaarid sõltumatult kolleegilt, kes töötab klaveriõpetaja ja kontsertmeistrina. 


\section{ELEVANDI MARSS}

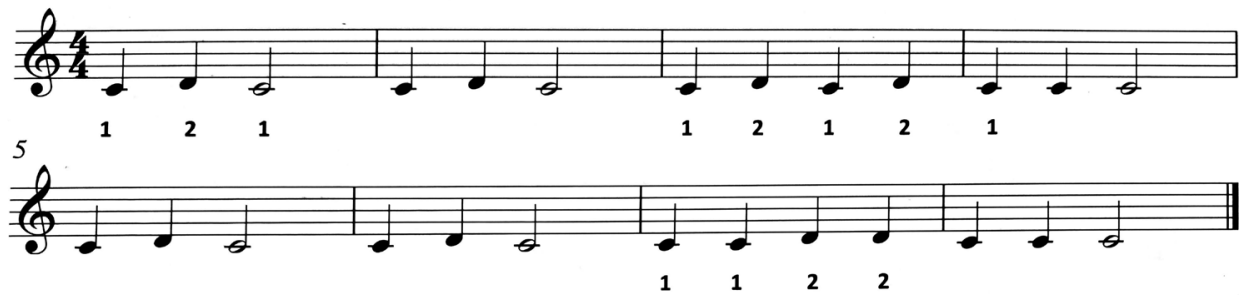

Joonis 3. Loo "Elevandi marss" noot.

JUBA LINNUKESED

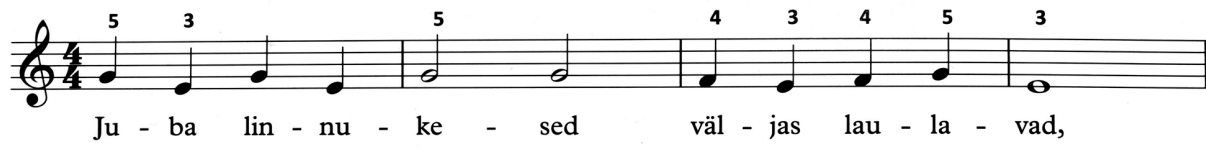

5

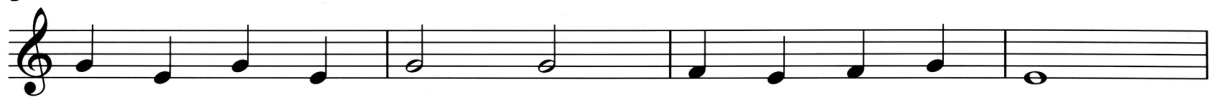

ke - nad ka - se - ke - sed kin - gul ko - ha - vad.
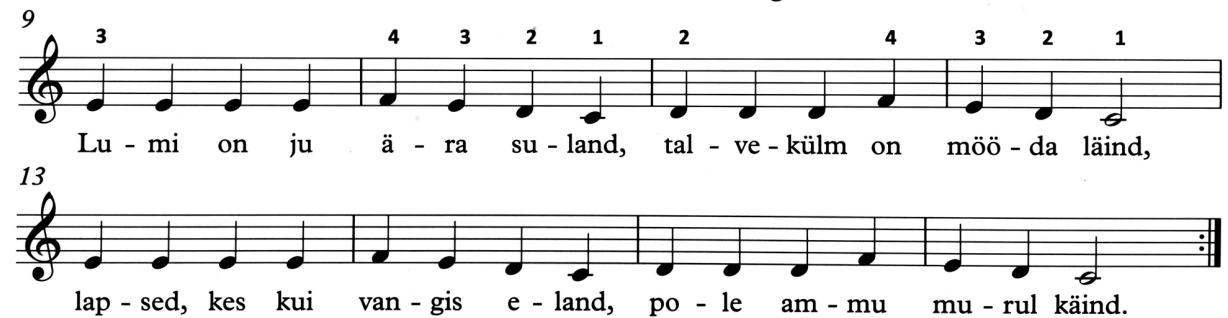

Joonis 4. Loo "Juba linnukesed" noot.

AISAKELL

Traditsionaalne
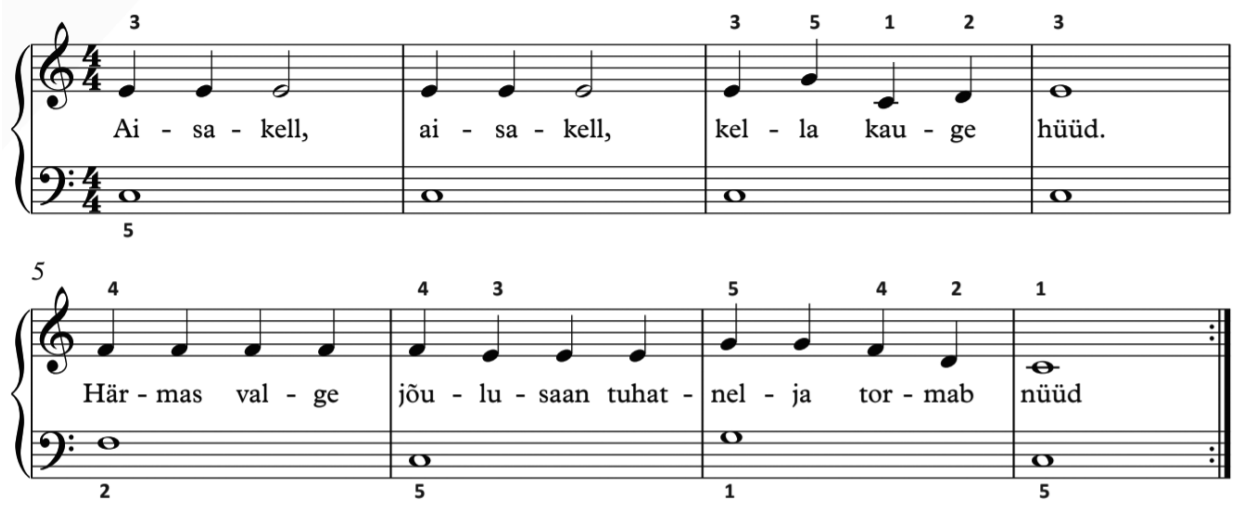

Joonis 5. Loo "Aisakell” noot. 


\section{3. Õpilaste lugude omandamise analüüs}

Järgnevates näidetes on kõik nimed muudetud. Uurimistööga varasemalt mitte seotud olnud kolleegi kommentaarid on tähistatud algusega: "Õp T:".

Videotele pääseb ligi ainult selle lingi kaudu:

https://www.youtube.com/playlist?list=PLSfeJ_vlFphxn0zSX8YF23WRhz1tEqlmB

Järgnevatest näidetest on täielikud litereeringud leitavad siit:

https://docs.google.com/document/d/18ePUP6U-9yi5DfJMkIshc4fslg00qHp

itePDcXSVCbY/edit?usp=sharing

\subsection{Jassi näide}

Jass oli seitsmeaastane ning käis esimeses klassis. Klaveriõpinguid alustas ta koos kooliga: esimesse klassi läks 2018. aasta septembris, klaveritundidega alustas oktoobris (minu juures). Oktoobris käis ta klaveritundides ühel korral nädalas, sealt edasi kaks korda nädalas. Uurimistöös vaadeldakse vahemikku oktoobri algusest kuni detsembri keskpaigani.

Antud näitest looga "Elevandi marss" nähtub, et kuigi Jassil on hea mälu, mängib ta noodist siiski õigemini kui peast. Mängides lugu, noot ees, ei kipu ta pilku sõrmedele suunama, vaid mängib, jälgides hoolikalt nooti.

Õp T: “Tundub, et noodist tuleb lugu paremini välja. Kui mõni tund veel see lugu ette võtta, tuleb ilmselt peastmäng paremini. Tegu on võrdlemisi lihtsa looga, nii et arvan, et noodist ja peastmäng oleks tulevikus võrdsel tasemel. Antud näite järgi mängis Jass noodist paremini."

Näide looga "Juba linnukesed" vastandub eelmisele näitele. Mängides noodist teeb Jass palju vigu ja tekivad pausid. Peast mängides nii palju vigu ei tule, mäng on hoolikam ja ühtlasem. Huvitav on see, et kuigi ilma noodita peast mängides tuli tal esitus paremini ja üsna kindlalt, tundub, nagu ta tunneks mingit kohustust vaadata nooti või kontrollida noodist oma teadmisi.

Õp T: "Kuna see on lastele tuttav lugu, siis üldiselt see tulebki "kuulmise järgi” ehk peast paremini välja. Noodipilt tundub lapsele hüplev ning kirju oma paljude noodikordustega. Kõik oleneb muidugi lapsest, tema taibukusest ja ka kohati arenguastmest (vanuselisest vms)."

"Aisakell" on antud näidetest kõige raskem lugu, kuna mõlemad käed peavad koos mängima samaaegselt. Loo selgeks õppimine läks üsna kiiresti, sest ta luges nooti üpriski hästi. Kui lugu oli juba selge, oli raske vahet teha, kumb variant oli parem - kas peast mängitud variant või noodist mängitud variant. Tundub, nagu põimuksid antud näites eelmised kaks näidet - noodist mängides on ta pisut enesekindlam, aga ka peast mängides tuleb kenasti. 
Õp T: “Tegemist on jälle lastele tuttava looga ning neile meeldib seda õppida, seetõttu ka ilmselt „varajane“ päheõppimine õpilase enda initsiatiivil. Arvan, et lugu oli noodist mängides siiski julgemalt esitatud kui peast.”

Antud juhul ei paista minu silmis kumbki õpimuster väga selgelt eristuvat, õp T arvates tuleb enamasti noodist paremini välja. Jassil on nii küllalt hea mälu, kui ka üpriski kiire noodist lugemise oskus. Mõlema mänguviisi puhul on nippe, mis aitavad ühel või teisel viisil mängida, kuid mida ta veel pole õppinud. Küll aga on kõnekas poisi vastus viimases tunnis otsesele küsimusele tema enesetunde kohta eri viisil mängimise puhul - noodist on lihtsam.

Kui tema enda eelistus on noodist mängida, siis on tõenäoline, et isegi kui anda mõlema mänguviisi juurde abistavad nipid, ei muutu kummagi mänguviisi omavaheline suhe - lihtsamaks saavad mõlemad, aga noodist mängimisel on ikka eelis.

\subsection{Reinu näide}

Rein oli seitsmeaastane ning käis esimeses klassis. Kooliga alustas 2018. aasta septembris, klaveritundidega 2019. aasta veebruaris (minu juures). Klaveritunnid toimusid läbivalt üks kord nädalas ning uurimistöös käsitletud materjal on pärit vahemikust veebruari keskpaik kuni aprilli lõpp.

Esimesest katsest Reinuga tundub, et kuigi ta jälgis noodist mängides hoolikalt nooti, on tal ka küllalt tugev peast mängimise oskus. Huvitav on seejuures tähele panna, et peast mängides ei vaata ta oma käsi, nagu tavaliselt peast mängides tehakse, vaid vaatab sihitult otse ette või isegi üles.

Õp T: "Uskumatu, et ta nii vähese ajaga loo peast mängis!"

Teine näide paistab kinnitavat esimest, ent ilmneb ka kalduvus eelistada noodist lugemist peast mängimisele. Noodist mängides vaatab ta küll vahel käsi, ent siiski päris palju nooti. Seekord tuleb noodist mängides vigu vähem ning on tunda suuremat enesekindlust. Peast mängides on seekord pilk enamasti siiski suunatud kätele, ainult vahel mõttepausi ajal või raskemat kohta alustades suunab pilgu sihitult ette.

Õp T: “Taas peab nentima, et lastel on hea peast mängida, sest lugu on tuttav. Arvan, et noodist- ja peastmäng on selle loo puhul võrdses olukorras, kuigi tulevikus tuleb kindlasti peast paremini. Nagu noodiõppimine, vajab ka pähe õppimine aega ja tööd."

Viimane tund oli 14. tund, sest 13. tunnis ei olnud lugu veel piisavalt selge (s.t "esimesed kaks takti tulevad ilusti, kolmas takt tuleb vaevaliselt. Taktide vahel läheb aega, et käsi sättida. Silmad vaatavad üldiselt nooti, välja arvatud käte sättimise ajal”). Selles tunnis lugu noodist mängides on ambitsioonid 
suured ja oskused veidi väiksemad, ent loo esitus jõuab lõpuni üpriski äratuntavalt antud loona. Pärast mõningast tööd noodiga peast mängides jääks lugu katki juba pärast esimest kahte takti, kui poleks vahepeal abi, ent isegi pärast noodi ülevaatamist tekib raskusi teose lõpuni jõudmisega. Kolmas näide kinnitab eelnevas näites ilmnenud kalduvust veelgi tugevamalt. Kuigi ka noodist mängides tekib vigu ja mõttepause, tuleb tervikesitus peast mängides veelgi vaevalisemalt.

Õp T: “Tundub, et õpilasel oli mõningaid raskusi juba noodist mängimisel, peast mängul ei olnud seega n-ö võimalustki muusikat korrektselt esitada."

Reinu puhul on minu meelest üsna selge, et kalduvus noodile toetuda on oluliselt suurem kui kalduvus lugusid peast mängida. Õp T arvates oskaks Rein paremini peast mängida, kui ta saaks lood paremini selgeks. Peast mängimine on talle oluliselt suurem väljakutse ja vajab rohkem tööd. Ka tema enda arvates on noodist mängimine parem. Seega võib öelda, et oma õpimustri poolest on antud jaotuses Rein n-ö noodilugeja.

\subsection{Nele näide}

Nele oli seitsmeaastane ja õppis esimeses klassis. Kooliskäimist alustas ta 2018. aasta septembris, klaveritunnis hakkas käima 2019. aasta märtsis. Klaveritunnid toimusid üks kord nädalas ning uurimistöös käsitletud tunnid toimusid vahemikus märtsi algusest kuni juuni keskpaigani.

Esimesest katsest Nelega näib, et kuigi ta loeb võrreldes eelmiste lastega oluliselt kiiremini nooti, jääb talle õpitav lugu väga hästi meelde. Huvitav on täheldada, et kuigi ta mängis peast kiiresti, soravalt ja täiesti õigesti, millest võiks välja lugeda enesekindlust, näitavad tema kommentaarid hoopis vastupidist.

Õp T: “Tundub, et ta on hea mäluga neiu, kuigi jah, tegu on ka lihtsa looga. Hindaksin noodist ja peast mängu võrdseks, aga jah, peast tuli natukene paremini."

Teises näites tuleb noodist mängimine Nelel paremini välja kui peast mängimine, kuigi mõlemal juhul jõuab ta ilusti lõpuni. Nele paistab silma selle poolest, et nii selle, kui ka järgmise loo puhul hakkab ta noodist mängides kuidagi iseeneslikult häälega vaikselt oma mängule kaasa laulma.

Õp T: “Jälle pean nentima, et peast on seda lugu hea lihtne lastel mängida, kuigi noodist tuli paremini välja."

Nele ei tahtnud 13. tunnis kahekäe lugu ("Aisakell”) mängima hakata (üldse), mistõttu lükkusid katsed tunni võrra edasi. Järgmises tunnis oli raske hinnata, kumb variant tuli Nelel paremini välja - mõttepause ja valesid noote esines nii noodist kui ka peast mängides. Küll aga tundub mulle, et vead noodist 
mängides tulenesid sellest, et kuigi pilk oli suunatud nooti, mängis ta lugu osaliselt peast ja nooti kasutas enda kontrollimiseks. Otse noodist mängides ei tohiks juhtuda näiteks sellist viga, et ta mängib (kuuenda takti parem käsi) kolm nooti ilusti järjest ära ja pärast pausi alles eelmiste nootidega korduva viimase noodi - sellest järeldaksin, et vahepealsed noodid olid tal peas, mitte noodist loetud. Samuti tundub peast mängimine olevat vasaku käe valede nootide põhjus - ta ei jäta neid mängimata, mis oleks loogiline viga, kui ta mängib noodist ja lihtsalt unustab vasakut kätt lugeda, vaid ta mängib sinna mingi noodi, mille siis tagantjärele parandab (näiteks viiendas ja kaheksandas taktis).

Õp T: "Nele paistab olevat hea kuulmisega, seetõttu ka eelnevate lugude üsna korralik peast esitamine, samuti ka selle looga. Tuttav lugu, seda on lihtsam peast mängida pärast mõningast harjutamist. Hindaksin noodist mängu ja peast mängu võrdseks."

Kuigi Nele mängib küllalt soravalt ka noodist, tundub ta minu meelest olevat siiski pigem peastmängija. Õp T arvates on Nelel noodist ja peast mäng võrdsed, v.a teises näites, mil tuli noodist paremini.

\subsection{Inese näide}

Ines oli seitsmeaastane, käis lasteaias ja eelkoolis ning läks kooli sügisel. Klaveritundidega alustas ta 2019. aasta märtsi alguses, käies tunnis üks kord nädalas ning uurimistöös on käsitletud tunnid kuni mai lõpuni.

Näites "Elevandi marss" tundub, et kuigi Ines mängib ka peast küllalt hästi, on ta noodist siiski parem mängija ning tunneb end seejuures paremini. Peast mängides läksid ainult esimese ja teise rea kolmandad taktid omavahel vahetusse. Pisut kummaline on, et hoolimata minu kiidusõnadest ei näidanud ta peaaegu üldse välja head meelt oma hea tulemuse üle peast mängimisel.

Õp T: "Seda viga juhtub õpilastel tihti, et väikeste muudatuste puhul noodis kahe rea vahel, tekib segadus ja mängitakse kaks rida samamoodi. Noodist tuli siiski paremini välja."

Pärast nelja tundi teise loo õppimist, mängis Ines teose noodist mõnevõrra paremini kui peast, kuigi mõlemal juhul jõudis ta lõpuni. Pärast katset mängisime üks kord veel noodist ning ta sai ise aru, mis viga tal enne peast mängides tuli.

Õp T: "Mulle tundub, et nii noodist- kui ka peast mäng vajavad veel veidi harjutamist, kuid selle näite põhjal tuli kindlasti noodist mäng paremini välja."

Inese puhul on märkimisväärne, et 10. tunnis me ei jõudnud loo "Aisakell" õppimiseni, sest õppeprotsess kulges temaga aeglasemalt. Seetõttu alustasime selle loo õppimist üldarvestuses alles 11. tunnis. Küll aga tuli ta 12. tundi selle 
looga nii, et see lugu oli tal peaaegu veatuks õpitud. Seega otsustasin teha temaga peast mängimise katse juba siis. Viimases (12.) tunnis tulevad mõlemad esitused küll mõningaste pausidega ent praktiliselt veatult.

Õp T: “Õpilane oli tublisti loo kodus selgeks õppinud, seetõttu ka suurepärane noodist mäng. Ka peast mängul polnud viga. Väga tubli, et edasi pusis, vaatamata suurele mõttepausile."

Inese näidete puhul tekib selge muster, mille osas oleme üksmeelel nii mina kui õp $\mathrm{T}$, et kuigi ta on ka hea peast mängimisel, mängib ta noodist alati paremini - veatumalt ja enesekindlamalt.

\subsection{Anna näide}

Anna oli seitsmeaastane, alustas kooliga 2019. aasta septembris ning klaveritundidega oktoobri alguses. Käis tunnis üks kord nädalas, uurimistöös käsitletud tunnid kestsid kuni 2020. aasta veebruari alguseni.

Viiendas tunnis esimest korda noodist mängides lähevad segamini sümbolid ja nende tähendus - ühelöögilist nooti tõlgendab ta $c$-noodina ja kahelöögilist nooti tõlgendab ta $d$-noodina, noodi pea asukoht ei paista tema silmis tähendust omavat. Pärast märkide ülekordamist jõuame siiski õige esituseni. Samas tunnis esimest korda peast mängides tekib esialgu paanika ja kogu ettekannet saadab ebakindlus.

See on huvitav näide. Kui noot on ees, on minu meelest selge, et ta mängib hea meelega peast - niipea, kui ta arvab, et ta on aru saanud, mis noodis on, mängib ta seda peast. Samas, kui proovida peast mängida nii, et noot ees ei ole, muutub ta oluliselt ebakindlamaks ja arvab ise, et tal ei ole midagi pähe jäänud. Katse tulemused näitavad aga, et suuremas osas on lugu siiski juba peas.

Õp T: "Huvitav näide... mulle jäi mulje, et õpilasel toimub peas samal ajal 1000 muud asja peale klaverimängu, just selles mõttes, et kui õpetaja räägib, siis klimberdab jms. Õpetajal on nii kindlasti raskem tööd teha. Tundub aktiivne ja sõnakas laps. Noodist mängis ta minu arvates igal juhul paremini, kuigi jah, ebakindlus võttis peast mängult oma osa. Tegelikult on tal ilmselt paremini peas, kui välja tuli.”

Anna puhul on erakordne, et ta tahtis seda lugu peast mängida juba 9. tunni alguses (loo õppimist alustasime 8. tunnis), ilma et ma oleks andnud sellekohaseid juhiseid kodus harjutamiseks. Kuna lugu oli veatu ja selge, siis me rohkem selle looga tööd ei teinud. Tema puhul võib olla mõjutavaks teguriks asjaolu, et tema ema on lõpetanud omal ajal muusikakooli noorteosakonna ning aitab Annal kodus harjutada. 
Õp T: “Tundub, et Anna lemmiklugu. Ei oska kuidagi hinnata, sest õpilasel oli juba lugu peas... ja noodist mänguga võrrelda ei saa."

Pärast kolme tundi tööd kolmanda looga, oli tal 4. tunnis (üldarvestuses 13. tund) endiselt suuri raskusi nii ühe kui ka kahe käega mängimisel, nii noodist kui peast (ma vahepeal küsisin, kas tal äkki tuleb ilma noodita paremini ning ta nõustus, ent esitus ei läinud sellest paremaks). 14. tunnis rääkisin temaga pikalt, et ta oleks nõus seda lugu üks kord veel mängima (kuna jõulud olid ammu möödas, on vastumeelsus arusaadav). Saime kokkuleppele.

Kuigi lugu oli peaaegu peast mängitud, tuli sisse üsna palju vigu ning päris noodita ikka ei saa - üks kord tundis vajadust kasutada selle abi. Kohati tekib sarnasusi Nele näitega, näiteks kuuendas taktis, kus vasak mängib $c$ asemel $f$ hoolimata sellest, et ta vaatas sel hetkel nooti.

Õp T: "Mulle tundub, et sellel õpilasel on vaja rohkem peast mängimise praktikat, et harjuda mõttega, et ilma noodita on ka võimalik. Annal tuleb peast (peaaegu) välja ja tegelikult ilmselt ongi peas, aga noodiga on esitus kindlam. Kuna lugu polnud päris hästi selge, siis on ilmselge, et tekib raskusi ka peast mängimisel."

Anna tundub kalduvat antud jaotuses üsna tugevalt n-ö peastmängijate poole. Tunnis esinevatest vestlustest nähtub ka, et noodi mõistmine ja selle lugemine on tema jaoks vaevaline. See toetab John Sloboda teooriat, et õpilaste kalduvus toetuda peast mängimisele võib tuleneda ülesannete liigsest arvust ja noodist mängimise raskusest (Sloboda 1985: 73). Samas õp T arvates on esimesel ja kolmandal juhul selge, et noodist tuleb esitus parem ja teist juhtu ei saagi hinnata.

\subsection{Emma näide}

Emma oli seitsmeaastane, õppis esimeses klassis alates 2019. aasta septembrist ja klaveritundidega alustas oktoobri esimeses pooles. Käies tunnis üks kord nädalas jäid uurimuses käsitletud tunnid vahemikku oktoobri esimesest poolest kuni 2020. aasta märtsi esimese pooleni.

5. tunnis esimest korda noodist mängides tunduvad $c$ - ja $d$-noodid olevat omavahel segamini. Kui aga esimene takt saab paika, läheb ka edasi kenasti. Samas tunnis esimest korda peast mängides tuleb algus üsna enesekindlalt, mõningaste meenutuspausidega, mis aga järjest pikenevad, kuni teise reani, mis ei tulegi meelde. Mõlemad esitused võib minu meelest lugeda suhteliselt võrdseteks - ühel juhul oli vaja aidata algust, teisel juhul lõppu.

Õp T: “Õpilasel läks noodist mäng alguses raskelt, kuid kui $c$ ja $d$ erinevus noodipildis silmade ees selgemaks sai, siis polnud probleemi. Peast mängimisel 
vastupidi - algus tuli kergelt ja lõpus läks meelest ning pidi nooti kasutama. Hindaksin samuti võrdseks nii noodist mängu kui peast mängu.”

12. tund kahjuks ei salvestunud ja seega toon siin välja nädal aega hiljem toimunud 13. tunni, kus ta tahtis omaalgatuslikult mängida kohe esimesena seda lugu. Loo esitus noodist tuli mõnede kahtluste (enne mängimist vaikselt järeleproovimiste) ja väikeste noodivigadega, ent ta suutis ise vead parandada ning iseseisvalt loo ilusti otsast lõpuni mängida. Ta jäi veendunuks, et vasaku käega on seda lihtsam mängida, kuigi ta ise on paremakäeline. Hiljem selles tunnis proovisime ka kahe käega mängida, paremaga mängisime uuesti järgmises tunnis.

Tehnilistel põhjustel jääb kahjuks peast mängimise katse siinkohal kirjeldamata, ainus jäädvustatud vihje 11. tunnist (ehk ainult selle loo arvestuses 4. tunnist) viitab sellele, et Emma eelistab lugusid mängida noodist.

Kuigi peast mängimise katse ebaõnnestus, saab siit vähemalt nii palju välja lugeda, et peast mängimine talle meele järele ei ole.

Õp T: "Noh... seda ei saa hinnata."

13. tunni, kus toimus katse kolmanda looga, salvestus katkes ja ma ei saanud sellest teada enne tunni lõppu. Seega salvestuse saamiseks tegin veel 14. tunni ja toon siin välja selle. Esitus noodist (kui ta veel ei teadnud eesootavast katsest) oli küll mõningate koordinatsiooniraskuste ja mõttepausidega, ent õpilane tundub teadvat, mida ja kuidas tegelikult mängima peaks. Kohe järgmiseks teeme katse peast mängida. Minu üllatuseks tahtis ta kõigepealt mängida eraldi kätega peast, siis korra veel noodist kahe käega ja alles siis oli nõus proovima mängida kahe käega peast.

See on keeruline näide, sest ma ei saanud kohe pärast esimest noodist esitamist ühte kahe käega esitust peast. Samas saab selle näite puhul teha huvitavaid tähelepanekuid.

1. Selle põhjal, et ta tahtis enne kahe käega peast mängimist kõigepealt eraldi kätega peast mängida, võib minu meelest teha järelduse, et tema aju ei töötle kahe käega esitatuna seda lugu mitte niivõrd kooskõlade järgnevusena kuivõrd kahe eraldi liinina, mida tuleb mängida samaaegselt.

2. Reaktsioonid ettepanekule mängida teost peast tundusid pigem vastumeelsed ja isegi pärast eraldi kätega peast mängimist tahtis ta enne kahe käega peast mängimist veel kord kahe käega noodist mängida. Nendele tähelepanekutele toetudes järeldan, et ta tunneb ennast oluliselt kindlamalt mängides noodist.

3. Lõpuks kahe käega peast mängides tuleb Emmal minu arvates esitus paremini kui varasematel kahe käega noodist mängimistel, mis viitaks justkui vastupidisele, samas see võib tuleneda pikemast ettevalmistusest, mis ta endale võimaldas enne kui oli nõus kahe käega peast mängima. 
Õp T: “Tõesti huvitav näide: õpilane tunneb end paremini noodiga (kes meist mitte), kuid lõpuks oskab ka peast võrdlemisi hästi. Ma siiski hindaksin tema noodist mängu paremaks kui peast mängu."

Emma puhul tundub mulle noodist ja peast mäng küllalt tasavägine. Kuna aga teine näide ja ebakindlus kolmandas näites peast mängimisel viitavad pigem noodist mängimise eelistusele, hindaksin teda olevat pigem orrnalt noodist mängija soodumusega. Ka õp T kommentaaridest võib järeldada, et otsus on keeruline ning noodist ja peast mängimine õnnestuvad üsna võrdväärselt: esimene näide viitab tasavägisusele, teist ei saa hinnata ja kolmas on parem noodist esitamisel.

\subsection{Järeldused}

Tehtud töös esinevad mõned vajakajäämised. Vahetevahel vedas alt minu tehniline lahendus - telefoni aku tühjaks saamise, mälumahu täissaamise või mõne muu põhjuse tõttu, mis mul õigel ajal märkamata jäi, olid mõnede tundide salvestused poolikud ning mõni tund ei salvestunud üldse.

Samuti osutus oodatust keerulisemaks ülesandeks järgida samaaegselt

a) esimese õpilase põhjal koostatud märksõnalist tundide päevikut,

b) uurimistööks olulisi piiranguid (näiteks õpilase nime vm delikaatse info mainimata jätmist, peast mängimise ülesande andmisest hoidumist jms),

c) hetkel tunnis oleva õpilase emotsionaalset ja vaimset seisundit (nt väsimus, vastumeelsus),

d) lapse arenguvajadusi, pidades meeles tema senise arengu käiku (millised teemad olid tema jaoks keerulisemad, millised hoopis väga lihtsad).

Hoolimata nendest asjaoludest õnnestus koguda uurimuses osalenud õpilastelt mitmekülgset, informatiivset ning kvalitatiivset andmestikku, mida pean piisavaks, et vastata tõenduspõhiselt antud uurimistööga esitatud küsimusele. Videote litereeringutest leiab infot nii teoste esituse arengu, esituse kvaliteedi kui ka õpetamismeetodite ning õpilase suhtumise kohta kõikide õpilaste puhul.

Kõik juhuslikult ja vabatahtlikult uurimuses osalenud õpilased osutusid erinäolisteks ja huvitavateks isiksusteks. Esines nii selget eelistamist kasutada teose esitusel noodi tuge kui ka mitte väga head läbisaamist nooditekstiga ning mälu võimaluste soosimist ja rakendamist. Kuuest lapsest neli (Jass, Rein, Ines ja Emma) toetuvad meelsamini noodile ning kaks (Nele ja Anna) oma mälule. Sellise tulemuse saamisel on arvesse on võetud nii nende läbitud katsetes tehtud esituste kvaliteeti emma-kumma mängimisviisi puhul kui ka nende isiklikke arvamusavaldusi ja reaktsioone. Seejuures on oluline rõhutada, 
et erinevalt uurimistöö alguses välja toodud diskreetsele kategoriseerimisele, eendub nende näidete põhjal pigem spektraalne pidevjaotus ehk tugevamad ja nõrgemad soodumused ühele või teisele poole. Et saada kogutud andmetest mingit visuaalset ettekujutust, omistasin sõnalistele määratlustele arvulised väärtused - kui õpilane mängis noodist paremini ühe loo, sai ta -1 punkti, kui mängis peast paremini ühe loo, sai ta +1 punkti, kui ühe loo katses erinevust ei tekkinud, siis 0 punkti. Nii saab nt Nele kolme loo peale $+1-1+1$ punkti ehk kokku +1 ühe punkti ja graafikult on näha, et noodist $v s$. peast kontiinumil kaldub ta ainult kergelt peast mängijate suuna poole, samas Ines, kes mängis kõik lood noodist paremini, saab kokku -3 punkti ning kaldub seega kontiinumil n-ö äärmuslikult noodist mängijate suunas.

Lisaks noodist ja peast mängimise tendentsidele tulid välja ka teistsugused käitumismustrid. Huvitav oli märgata, et noodilugejad vaatavad peast mängimisel aeg-ajalt enda ette (sinna, kus enne oli noot noodipuldil), peast mängijad aga vaatavad peast mängimisel alati kätele ning ka noodilugemisel käib pilk käte ja noodi vahel. Nii Nele kui ka Anna (peast mängimise soodumusega) hakkasid vahetevahel spontaanselt oma mängimisele kaasa laulma, samas kui teised isegi minu ettepaneku puhul teost läbi laulda, ei suhtunud laulmisse kuigi entusiastlikult.

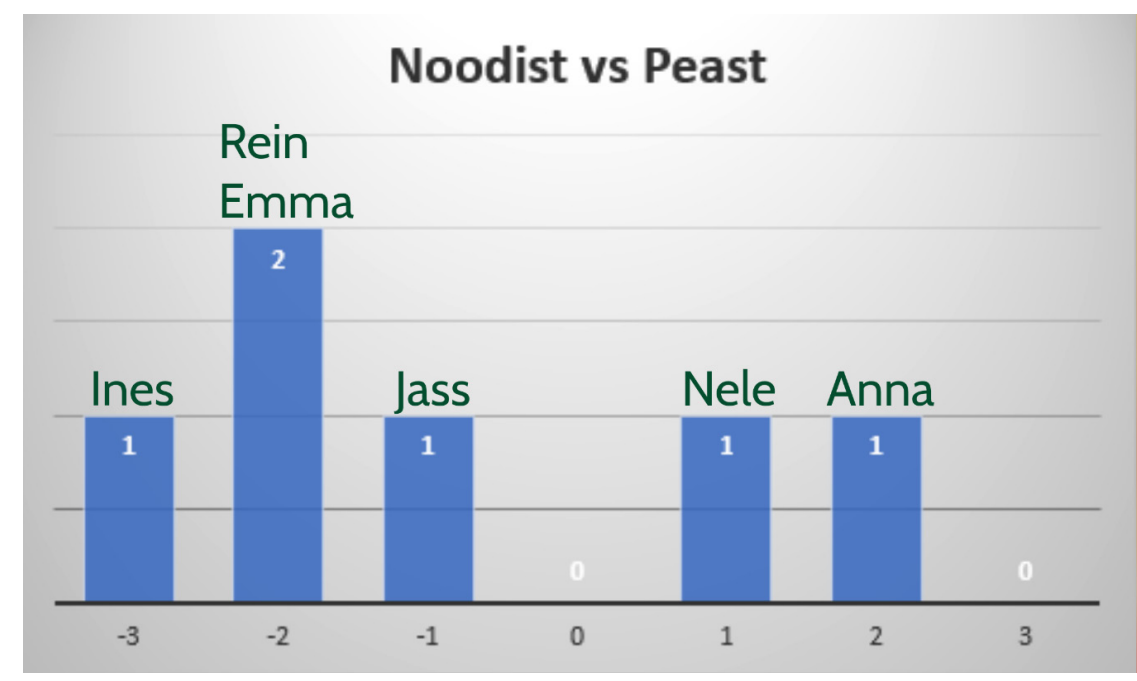

Joonis 6. Õpilaste jaotumine noodist ja peast mängija õpimustrite kontiinumil. 
Oma näidetele ja kommentaaridele lisaks palusin kõrvalist pilku ka kolleegilt, keda selles töös tähistasin kui õp T. Kuigi mitmel juhul erines minu hinnang kolleegi hinnangust, tulid siiski mitmel juhul õpilaste erisused välja. Tasub märkimist, et kolleeg töötab õpetamise kõrvalt ka kontsertmeistrina ning väljendab oma kommentaarides seisukohta, et tema arvates on kõigil lihtsam noodist mängida (vt näide 3.6.3.). Mina temaga selles osas nõus ei ole, kasvõi oma tegevust silmas pidades, aga püüdsin jääda oma hinnangutes võimalikult erapooletuks.

\section{Kokkuvõte}

Olen täheldanud oma praktikas ja kuulnud ka teistelt sama ala inimestelt nähtusest, mis viitab sellele, et vähemalt klaveriõppes joonistuvad õpilastel välja õpimustrid. Avalduvad mustrid väljenduvad suuremas plaanis selles, kas õpilane eelistab vaistlikult teose omandamisel ja esitamisel toetuda pigem noodile või pigem mälule.

Algõpetuses tuleb lähtuda sellest, et õpilasel puuduvad varasemad teadmised ja oskused, mis on vajalikud klaverimänguks ning klaveril teoste esitamiseks. Õpilaste muusikaline taust baseerub otseselt teda ümbritseval kultuuril. Seega on oluline õppida muusika ja klaveriga seotud õppematerjali järk-järgult, mänguliselt ja palju korrates. Sellele vaatamata on pillimängu õppimine äärmiselt keerukas tegevus, millesse on kaasatud mitte ainult aju, vaid ka kogu keha (lisaks käte tegevusele on oluline ka istumisasend ning pingevaba kehatunnetus).

Teose mängimisel noodist on õpilasel vaja tajuda noodis sisalduvaid stiimuleid, neid mälu abil lahti kodeerida, koostada motoorne kava stiimuli seatud ülesande teostamiseks, kava teostada, tekkinud tulemust analüüsida ning sellele reageerida - kas püüda sama ülesannet paremini täita või liikuda järgmise juurde. Noodist mängimise edu võti on hästi omandatud teadmised ja oskused, mis võimaldavad kiiresti noodist aru saada ja selles sisalduva info järgi tegutseda.

Peast mängides salvestab õpilane noodist tajutud stiimulid, nende tähenduse ja nendega kaasneva tegevuskava oma mällu ning mängib edaspidi rohkem mälule toetudes. Muusikalisse mälusse on kaasatud erinevad mäluliigid, mis igaüks täidab erinevat ülesannet: kuulmismälu abil kujutleb õpilane teose helisid; visuaalse mälu põhjal meenutab noodipilti ja mäletab mängu keskkonnaaspekte; motoorne mälu aitab sooritada keerukamaid liigutuslikke järgnevusi automaatselt; kajamälu annab vahetu kogemuse ning aitab segmenteerida seda kontrollitavateks üksusteks, pikaajaline mälu võimaldab suhestada õpitu 
laiemasse raamistikku. Peast mängimise edu võti on oskus muusikalist infot seostada ja oma mälu võimalusi kasutada.

Õpistiili kasutusel oleva laia tähendusvälja, välja kujunemata üldtunnustatud definitsiooni ning suure hulga puudulike või muul põhjusel ebausaldusväärsete uurimuste ja eksperimentide tõttu on see teema tekitanud palju vaidlusi nii minevikus kui ka tänapäeval. Samas on selge, et õpilased on erinevad, ning tõenäoliselt on nende erinevuste põhjal võimalik teha üldistusi. Seetõttu on see teema püsinud pikalt päevakorras ning on endiselt arenev uurimissuund.

Selleks, et antud uurimuses käsitletava nähtuse olemasolu kindlaks teha, kaasasin uurimistöösse õpilased, kes on sobivas vanuses klaveriõpingute alustamiseks (seitsmeaastased) ega ole varem muusikalise süvaõppega kokku puutunud. Uurimistöö käigus viisin läbi 13-14 akadeemilist tundi, mille käigus õpetasin kõigile õpilastele samast õpikust samas järjekorras samu õpielemente (klaverimänguga seotud teadmisi ja oskusi) ja lugusid. Õpitud lugude seast tõin välja kolm näidisteost (samuti kõigil samad), millega tegin läbi katsed esitada teost ilma hoiatuseta noodist ja peast. Pärast omapoolset katsete analüüsi palusin ka kolleegil, kes polnud varem uurimistööga seotud, näited üle vaadata ning anda omapoolsed hinnangud ja kommentaarid.

Eksperimendi tulemustest võib välja lugeda õpilaste iseeneslikku soodumust toetuda teose õppimisel ja esitamisel rohkem kas noodile või oma mälule. Mõnel õpilasel tuli esitus kvaliteetsem siis, kui ta mängis noodist ning ta ise väljendas ka eelistust mängida noodi abiga. Mõnel õpilasel õnnestus esitus paremini aga siis, kui ta mängis teost peast ning nende puhul oli märgata peast mängimisele kalduvust ka siis, kui noot oli ees ja ma ei olnud palunud peast mängida. Seejuures on oluline märkida, et tulemuste põhjal on kahe õpimustri vastandamise korral tegu pigem kontiinumiga, kus õpilased kalduvad suuremal või väiksemal määral ühele või teisele poole.

Vastavate mustritega seoses avaldus ka käitumist, mida ma ei olnud osanud oma varasemas õpetajatöös nende stiilidega seostada: kui noodilugeja stiiliga õpilane püüdis peast mängida, ei püsinud tema pilk üksiti kätel/klahvidel, vaid oli suunatud vahel ka sihitult ette noodipuldi suunas või mujale; peast mängija stiiliga õpilased hakkasid aga aeg-ajalt spontaanselt oma mängule kaasa laulma.

Kuigi kõik kirjeldatud õpilased olid erinevad, tundub noodist- ja peastmängu muster joonistuvat välja juba esimeste kuude jooksul alates õppima hakkamisest. See ei saa olla tingitud erinevast enkulturatsioonist, sest lapsed on kasvanud samas piirkonnas ja kultuuris (Tallinn ja selle lähiümbrus), see ei saa olla tingitud ka kooli mõjutustest, sest enamik neist on alles kooli astunud, üks on alles valmistumas. Ka õpetamisstiilist ei saa see olla tingitud, sest õpetaja 
oli kõigil üks - mina. Kui defineerida õpistiili kui iseloomulikke kognitiivseid, efektiivseid ja psühhosotsiaalseid käitumisi, mis funktsioneerivad suhteliselt stabiilsete indikaatoritena õppijate taju, interaktsiooni ja reaktsiooni kohta õpikeskkonna suhtes (Curry 1981; Romanelli \& Bird et al. 2009 järgi), võib järeldada, et vähemalt klaveriõppes on seega olemas õpistiil.

Edaspidi saab uurida, millest tulenevad õpimustri suunad ja millega on need seotud, kas need esinevad ka teiste pillide õppes, kuidas see mõjutab õpilaste erialavalikuid tulevikus ning kuidas saab pedagoog nende stiilidega paremini suhestuda ja töötada.

\section{Tänuavaldused}

Artikli valmimist toetas Euroopa Liit Euroopa Regionaalarengu Fondi kaudu (Eesti-uuringute Tippkeskus, TK 145).

Soovime tänada toetuse, julgustuse, abi ja suunamise eest Eesti Muusika- ja Teatriakadeemia muusikateaduse eriala õppejõude ning interpretatsioonipedagoogika õppejõudu prof Lembit Orgset tagasiside ja kaasamõtlemise eest, kõiki kuut töös osalenud last ja nende vanemaid usalduse ja mu töö valmimisele kaasaaitamise eest, LA Klaverikooli direktorit Reet Lantsonit, kes lubas salvestada uurimistöö eesmärgil tunde LA Klaverikooli klassiruumides, sõltumatut kolleegi, kes vaatas näited üle ja andis omapoolsed hinnangud ja kommentaarid, ning ka oma sõpru, tuttavaid ja perekonda nende mitmekülgse toetuse eest.

\section{Lisa 1: Kokkulepe isikuandmete töötlemiseks uurimistöös}

Eesti Muusika- ja Teatriakadeemia (edaspidi EMTA) magistriastme tudeng Veeda Kala (tel. nr.: +372 5850 1779, e-posti aadress: veeda8@gmail.com) viib läbi uurimustööd, mille käigus ta salvestab enda läbiviidud klaveritunde, et leida tõendeid erinevatest õpilastele loomuomastest õpistiilidest, mis ilmnevad õppetöö käigus. Töö eesmärk on õpistiile tõendada ja kirjeldada, et tulevikus saaks õpetajad oma töös õpilastega paremini ja efektiivsemalt koostööd teha.

Olen oma lapse eestkostjana nõus, et minu laps osaleb uurimistöös, mille eesmärk on kirjeldada erinevatele klaveriõpilastele loomuomaseid õpistiile, ning sellega seoses võetakse tema klaveritunde ( 45 minutit on ühe tunni pikkus) videosse tingimusel, et: 
Mul on alati õigus küsida minu lapsega seotud materjali läbivaatamiseks; Minu lapse nime videosse võetava tunni käigus ei mainita;

Uurimistööga seotud materjalides on mu lapse nimi oluliselt muudetud;

Lapse pärisnime teab ainult uurimistöö läbiviija;

Kui avastan vähemalt ühe eelnimetatud punkti rikkumise, on mul õigus nõuda minu lapsega seotud materjali ja andmete kustutamist. Kui seda nõuet ei rahuldata, pöördun EMTA kontrolliva eetikakomitee poole, mille kontaktiks on Jaan Ross, jaan.ross@gmail.com.

\section{Kommentaar}

1 Jean Piaget - Šveitsi psühholoog, kes on tuntud laste arengupsühholoogia alaste tööde poolest.

\section{Kirjandus}

Aiello, Rita \& Williamon, Aaron 2002. Memory. Parncutt, Richard \& McPherson, Gary (toim). The Science and Psychology of Music Performance. New York: Oxford University Press, lk 167-181 (DOI: 10.1093/acprof:oso/9780195138108.003.0011).

Altenmüller, Eckart \& Gruhn, Wilfred 2002. Brain Mechanisms. Parncutt, Richard $\&$ McPherson, Gary (toim). The Science and Psychology of Music Performance. New York: Oxford University Press, lk 63-81 (DOI: 10.1093/acprof:oso/9780195138108.003.0005).

Fleming, Neil D. \& Mills, Colleen 1992. Not Another Inventory, Rather a catalyst for Reflection. To Improve the Academy. Professional and Organizational development Network in Higher Education (DOI: 10.3998/tia.17063888.0011.014, https:// digitalcommons.unl.edu/cgi/viewcontent.cgi?article=1245\&context=podimproveacad 18.11.2021).

Garcia, Susanna 2002. Learning Styles and Piano Teaching. Piano Pedagogy Forum 5 (1), 1. jaanuar (http://keyboardpedagogy.org/images/PPF/PPF\%20Vol.\%204-5.pdf 18.11.2021).

Hallam, Susan \& Bautista, Alfredo 2012. Processes of Instrumental Learning: The Development of Musical Expertise. McPherson, Gary E. \& Welch, Graham F. (toim). The Oxford Handbook of Music Education 1. New York: Oxford University Press, lk 658-676 (DOI: 10.1093/oxfordhb/9780199730810.013.0040).

Kirnarskaya, Dina 2009. The Natural Musician: on abilities, giftedness and talent (tlk Mark H. Teeter). New York: Oxford University Press.

Lantson, Reet 2014. Klaveriõpik lastele. Tallinn: CoPrint OÜ. 
Lehmann, Andreas C. \& McArthur, Victoria 2002. Sight-Reading. Parncutt, Richard \& McPherson, Gary (toim). The Science and Psychology of Music Performance. New York: Oxford University Press, lk 135-150 (DOI: 10.1093/acprof:oso/9780195138108.003.0009).

Leppik, Peep 2006. Õppimine on tõesti huvitav: õpiprotsessi psühholoogilisest mõtestamisest. Tartu: Tartu Ülikooli kirjastus.

McPherson, Gary E. \& Davidson, Jane W. 2006. Playing an Instrument. The Child as Musician. Toim. Gary E. McPherson. New York: Oxford University Press, lk 338-339 (DOI: 10.1093/acprof:oso/9780198530329.003.0017).

Romanelli, Frank \& Bird, Eleanora \& Ryan, Melody 2009. Learning Styles: A Review of Theory, Application, and Best Practices. American Journal of Pharmaceutical Education 73 (1) (DOI: 10.5688/aj730109).

Sloboda, John A. 1985. Muusikaline meel. Kognitiivne muusikapsühholoogia. Tallinn: Scripta Musicalia.

Snyder, Bob 2000. Music and Memory. An Introduction. Cambridge; London: The MIT Press.

Tomusk, Voldemar 1993. Oppistiilid. Tallinn: Tallinna Pedagoogikaülikool.

\title{
Summary
}

\section{The learning patterns in studying a piece of music in basic piano studies}

\author{
Veeda Kala \\ Estonian Academy of Music and Theatre \\ veeda8@gmail.com

\section{Jaan Ross} \\ Professor emeritus \\ Estonian Academy of Music and Theatre \\ Member of the Estonian Academy of Sciences \\ jaan.ross@gmail.com
}

Keywords: basic studies, learning, learning patterns, music, piano

This article was inspired by the first author's observations in the teaching process, which refer to different learning patterns in studying a piece of music. I have noticed that although I teach all the students by using quite the same methods, part of them remember the pieces rather quickly and they prefer to play and practise them from memory. Some others, on the other hand, prefer to play from notes, and they continue doing it during the whole learning process. The aim of this article is to find, by an evidence-based method, the occurrence of the abovementioned learning patterns and describe their characteristic features. In case peculiarities occur, which can be projected 
against the typology of different learning patterns, it is possible to study connections with the earlier learning styles and learning and information processing theories. It also enables us to offer applications for a more person-centred approach in piano pedagogy to enhance both the learning process, student-teacher collaboration, and the student's development as well as make them subjectively more pleasant for both parties. To investigate the learning patterns in basic piano studies, I video-recorded the classes with students of possibly similar backgrounds, giving them tasks testing their memory and note-reading skills. Based on the analysis of the collected information, I made conclusions about the existence and nature of hypothetical intuitive learning patterns. The interesting observations made by formal and non-formal examination add material for future in-depth studies, as the described phenomenon should be approached, above all, as a continuum, which enables us to estimate students' inclination towards one or the other side to a greater or lesser extent, and consequently, the application of a better adapted teaching strategies.

Veeda Kala on lõpetanud bakalaureuse klassikalise klaveri erialal aastal 2018 ning magistri muusikapsühholoogia erialal ja klaveripedagoogika kõrvalerialal cum laude Eesti Muusika- ja Teatriakadeemias aastal 2020.

Veeda Kala has a bachelor's degree in classical piano (2018) and master's degree cum laude in music psychology and piano pedagogy as a minor (2020) from the Estonian Academy of Music and Theatre.

veeda8@gmail.com

Jaan Ross lõpetas 1980. aastal Eesti Muusika- ja Teatriakadeemia cum laude muusikateadlase ja pedagoogina, 1988. a. kaitses kunstiteaduste kandidaadi väitekirja "Konsonantsuse objektiivsed eeltingimused muusikas" Leedu Muusika- ja Teatriakadeemias ning 1992. a. psühholoogiadoktori väitekirja Turu Abo Akadeemias. Ross on mitmete Eesti ja välismaa teadusühingute liige. Eesti Teaduste Akadeemia liikmeks valiti Ross 2003. aastal, aastatel 2009-2018 oli ta Euroopa Kognitiivsete Muusikateaduste Ühingu (ESCOM) juhatuse liige.

Jaan Ross graduated from the Estonian Academy of Music and Theatre cum laude as a musicologist and educationalist in 1980, defended his first doctoral thesis "Objective preconditions of consonance in music" in art sciences at the Lithuanian Academy of Music and Theatre in 1988, and his second doctoral dissertation in psychology at Åbo Akademi University in 1992. Ross is a member 
of several Estonian and international scientific societies. He was elected a member of the Estonian Academy of Sciences in 2003; in 2009-2018 he was a board member of the European Society for the Cognitive Sciences of Music.

jaan.ross@gmail.com 